\title{
GAYA HIDUP HEDONISME TERHADAP PERILAKU PEMBELIAN DI PASAR MODERN \\ (Studi Pada Masyarakat Kabupaten Kebumen)
}

\author{
Sigit Wibawanto
}

\begin{abstract}
Abstrak
Penelitian ini bertujuan melihat fenomena dengan gaya hidup hedonisme, tidak melihat dari tidak melihat faktor pendorong yang menimbulkannya. Penelitian ini hanya membahas pola gaya hidup dengan perilaku pembelian yang ditimbulkannya. Lingkup penelitian ini dibatasi pada gaya hidup hedonisme, yang mengacu pada teori Engel, dkk (1995) yaitu (activities), (interest), (opinion). Sedang perilaku pembelian masyarakat lingkup penelitian ini dibatasi pada dimensi skala shopping addiction yang dikembangkan Elizabeth E. Edwards yang disusun berdasarkan lima dimensi yaitu tendency to spend, drive to spend, feelings about shopping, dysfunctional spending, post-purchase guilt. Penelitian dilakukan di kabupaten Kebumen. Metode yang digunakan adalah metode survei, dengan membagikan kuesioner sebanyak 100 eksemplar kepada responden. Analisis yang digunakan analisis kualitatif dan kuantitatif. Dengan alat bantu analisis SPSS versi 23.0., hasilnya gaya hidup yang terdiri dari aktivitas $\left(\mathrm{X}_{1}\right)$, minat $\left(\mathrm{X}_{2}\right)$ dan opini $\left(\mathrm{X}_{3}\right)$ berpengaruh signifikan terhadap shopping addiction $(\mathrm{Y})$. Kesimpulannya unsur-unsur yang diakibatkan aktivitas, minat, dan opini masyarakat akan mendapatkan suatu perilaku pembelian yang abnormal dan membuat masyarakat mengeluarkan biaya untuk mendapatkan produk yang belum tentu sesuai kebutuhan, melainkan keinginan dan emosional dalam pengambilan keputusan pembeliannya
\end{abstract}

Kata kunci: Hedonism, Aktivitas, Minat, Opini, Shopping Addiction

\section{PENDAHULUAN}

Perkembangan pasar dengan techno market telah membawa pada kedewasaan berpikir dan berpengaruh terhadap pola konsumsi masyarakat. Pilihan dan keunggulan produk, pelayanan menjadi ajang pertempuran untuk menciptakan nilai pelanggan. Bisnis mengalami perubahan era, dari mass marketing menjadi mass customization. Perkembangan dan tingkat persaingan industri mendorong tumbuhnya variasi produk dan nilai yang ditawarkannya, mendekatkan produk serta kemudahan konsumen mengakses produk. Salah satunya adalah industri ritel yang saat ini pertumbuhannya telah luar biasa, dan ditempatkan sebagai satuan bisnis menarik bagi perusahaan manufaktur. Tingkat pertumbuhan penduduk, tingkat pendapatan, pola perpindahan tempat, selera atau tingkat konsumtif menjadi bagian pemikiran untuk menggolongkan dan memanfaatkan perbedaan dalam menciptakan produk dan merubah perilaku pembeliaan konsumennya. 
Perilaku konsumen adalah proses dan aktivitas ketika seseorang berhubungan dengan pencarian, pemilihan, pembelian, penggunaan, serta pengevaluasian produk dan jasa demi memenuhi kebutuhan dan keinginan (Duncan, 2005). Perilaku konsumen untuk membuat keputusan pembelian semakin komplek, pada harga yang mahal (highinvolvement), produk yang dicari dan dibeli memungkinkan keterlibatan konsumen semakin banyak dan sebaliknya pada barang yang berharga rendah (low-involvement), proses pengambilan keputusan konsumen mudah dan cepat. Menurut Engel, et al. (1994) adalah suatu tindakan yang langsung terlibat dalam mendapatkan, mengkonsumsi, dan menghabiskan produk dan jasa, termasuk keputusan mendahului dan menyusuli tindakan ini. Kemudian untuk memahami lebih lanjut mengenai perilaku konsumen, maka perlu mengetahui elemen pentingnya, yaitu proses pengambilan keputusan dan kegiatan fisik yang melibatkan individu dalam menilai, mendapatkan dan menggunakan barang dan jasa ekonomis (Swastha, 1990). Menurut Olson and Peter (2008) terdiri atas pendekatan interpretatif dimana pendekatan ini akan menggali secara mendalam perilaku konsumsi dan hal lain yang mendasarinya. Pendekatan selanjutnya adalah pendekatan tradisional yang didasari pada teori dan metode dari ilmu psikologi, kognitif, sosial, dan behaviorial serta dari ilmu sosiologi. Pendekatan yang terakhir dikenal dengan pendekatan sains pemasaran yang didasari pada teori dan metode dari ilmu ekonomi dan statistika.
Sikap terbentuk berdasarkan nilai-nilai yang diyakini pada suatu situasi yang spesifik dan digunakan oleh konsumen untuk memecahkan permasalahan dan mengambil keputusan (Homer \& Kahle, 1988). Sikap merupakan beberapa keyakinan terhadap suatu objek atau tindakan tertentu, di mana nilai menjadi kriteria yang digunakan untuk mengevaluasi perilaku konsumen (Schwartz, 1994). Secara teoritis, nilai dapat mempengaruhi perilaku seseorang karena nilai adalah kognisi yang paling abstrak, namun nilai akan berpengaruh terhadap perilaku dengan dimediasi oleh sikap. Schwartz dan Bilsky (1987) menjelaskan definisi konseptual tentang nilai secara komprehensif, yaitu nilai merupakan konsep atau keyakinan yang diharapkan untuk menentukan perilaku akhir, dalam situasi yang spesifik, menyeleksi atau mengevaluasi suatu perilaku dan peristiwa. Ketika sikap ini menjadi bagian penting terhadap perilaku, maka pemasar akan mempengaruhi perilaku pembelian konsumen (Simamora, 2004: 152. Konsep ini sesuai dengan definisi menurut Schiffman dan Kanuk (dalam Simamora, 2004: 152) yang mengungkapkan bahwa sikap merupakan ekspresi perasaan, yang mencerminkan apakah seseorang senang atau tidak senang, suka atau tidak suka, dan setuju atau tidak setuju terhadap obyek, yang dapat berupa merek, layanan, pengecer, perilaku dan lain-lain.

Sikap dapat mengubah perilaku, maka dalam penelitian ini penulis, melakukan penelitian untuk melihat pengaruh sikap yang 
mendasari perilaku terhadap pengambilan keputusan pembelian. Sikap yang dibahas sikap masyarakat yang dilihat dari afeksi, kognisi, perilaku dan lingkungan terutama akibat perubahan sikap masyarakat yang menuju gaya hidup hedonis pada bisnis ritel modern. Hedonisme merupakan pandangan hidup yang menganggap kesenangan dan kenikmatan materi adalah tujuan utama hidup. Hedonisme berasal dari bahasa Yunani (hedone) berarti kesenangan. Pencetus paham ini Aristipos dan Epikuros, yang melihat manusia melakukan aktivitas pasti untuk mencari kesenangan hidup. Hedonisme terbagi 2 aliran, yaitu menekankan pada kesenangan badan atau jasad, dan menekankan pada kesenangan rohani. Penulis yakin, saat ini peningkatan teknologi informasi, memberikan dampak pada individu, sehingga perlu kajian terhadap perubahan sikap, terutama pada perubahan perilaku konsumen. Fokus subyek penelitiannya adalah konsumen ritel modern dalam memenuhi kebutuhan fisiknya di Indonesia. Saat ini Indonesia memiliki penduduk lebih dari 220 juta, dan salah satu wilayahnya kabupaten Kebumen, penduduk wilayah ini cukup besar yakni berjumlah 1,3 juta jiwa sehingga menjadi menarik bagi bisnis ritel. Buktinya telah banyak bermunculan perusahaan ritel modern seperti supermarket maupun hypermarket, baik dikelola individu maupun persekutuan. Keberanian investasi beralasan, perubahan dinamika pembangunan dan pola konsumsi masyarakat menjadi dasarnya. Perkembangan teknologi informasi, kemudahan transportasi menjadi pengaruh yang kuat terhadap pengembangan pola pikir dan gaya hidup masyarakat. Keberadaan masyarakat Kebumen telah menjadi segmen potensial yang meningkat menjadi aktif dan agresif. Pasar modern kini bersaing dalam memberikan/ memanja segmennya dengan mengemas tokonya dalam tata ruang yang apik, terang, lapang, dan sejuk melalui pengalaman berbelanjanya. Segudang keinginan dan kemauan berbelanja masyarakat Kebumen sebagai pasar potensial, merubah gaya hidupnya, dan tidak sulit diidentifikasikan, misalnya rasa ingin tahu, suasana keramaian, dan terbatasnya hiburan yang ada di kota kecil ini. Produk pilihan yang menggiurkan membuat masyarakat Kebumen menjadi konsumen aktif dan sangat mudah berbelanja karena rasa ingin tahunya besar dan adanya suasana baru. Uang sering tidak terkontrol dan tidak menjadi persoalan dalam daya beli masyarakat Kebumen saat ini. Masyarakat yang telah memiliki pengalaman, juga semakin teribat sebagai provokator atau sebagai influencer bagi keluarga dan masyarakat. Fenomena tersebut diduga dapat menjadi pendorong terjadinya kecenderungan perilaku shopping addiction pada masyarakat Kebumen. Menurut Edwards (1993) shopping addiction merupakan suatu aktivitas berbelanja yang bersifat abnormal, dimana konsumen memiliki kekuatan yang kuat, tidak terkontrol, kronis, dan adanya keinginan berulang untuk berbelanja. Pelaku shopping addiction cenderung tidak mampu mengendalikan keinginannya atau mengontrol dirinya untuk berbelanja 
(shopping) sehingga melakukan apa saja secara berulang dan terus menerus agar keinginannya dapat terpenuhi, dan mereka juga tidak mampu untuk mengontrol diri (Moeljosoedjono, 2008). Shopping addiction dapat disebabkan oleh beberapa factor yang berasal dari diri sendiri, keluarga, dan lingkungan Siregar (2010).

Oleh karena itu, berdasarkan alasan-alasan tersebut, perubahan dan perkembangan dinamika masyarakat terutama pada gaya hidup hedonisme perubahan perilakunya menarik untuk diteliti. Penelitian melihat dan menganalisis pemahaman pasar konsumen masyarakat Kebumen yang berbelanja dengan sudut pandang pendekatan sikap hedonisme yang berkaitan dengan proses keputusan pembelian konsumen. Penelitian ini bertujuan melihat fenomena dengan gaya hidup hedonisme, tidak melihat dari mana munculnya gaya hidup hedonis, tidak melihat faktor pendorong yang menimbulkannya. Jadi, penelitian ini hanya membahas pola gaya hidup hedonisme yang terjadi dengan perilaku pembelian yang ditimbulkannya. Lebih mengenai bagaimana faktor pemicu, pendorong dan respon yang akan ditimbulkan menjadi menarik bagi penelitian berikutnya. Sehingga permasalannya dapat dirumuskan yaitu bagaimana pengaruh sikap hedonisme terhadap perubahan perilaku pembelian pada kabupaten Kebumen. Lingkup penelitian ini dibatasi pada aspek sikap hedonisme, yang mengacu pada teori Enggel, dkk (1995) yaitu minat dan kepentingan (interest), pendapat (opinion), aktivitas/ kegiatan (activities). Sedang perilaku pembelian masyarakat lingkup penelitian ini dibatasi pada dimensi skala shopping addiction yang dikembangkan Elizabeth E. Edwards yang disusun berdasarkan lima dimensi yaitu tendency to spend, drive to spend, feelings about shopping, dysfunctional spending, post-purchase guilt (Moeljosoedjono, 2008). Penelitian dilakukan di wilayah kabupaten Kebumen yang merepresentasikan populasi masyarakat di kota kecil yang saat ini telah memiliki perubahan sikap hedonisme. Penelitian ini diharapkan memberikan manfaat untuk mendalami referensi mengenai pengaruh keluarga lain yang telah memiliki pengalaman yang mempengaruhi pola berbelanja keluarga dalam setiap aktivitas berbelanja dan pilihannya terhadap pasar modern di sekitar wilayah penelitian ini. Disamping itu diharapkan penelitian ini bisa menjadi acuan untuk dapat dilanjutkan pada penelitan yang lebih spesifik terutama dengan pengendalian diri yang dipengaruhi atas keyakinan agama dan budaya masyarakat.

\section{TINJAUAN PUSTAKA}

Teori Perubahan Perilaku

Glanz, Lewis, \& Rimmers (1990, hal.17) menyarankan bahwa dalam merancang pelaksanaan atau intervensi program untuk menghasilkan perilaku yang terbaik dapat dilakukan dengan pemahaman tentang teori-teori perubahan perilaku dan kemampuan untuk menggunakannya dalam praktek (1990, p. 19). Sebelum memahami model perubahan perilaku, maka 


$\begin{array}{lrrl}\text { penting } & \text { untuk } & \text { memahami } & \text { Berikut pilihan daftar variabel dalam } \\ \text { sebelumnya } & \text { terhadap } & \text { variabel } & \text { model perubahan perilaku: }\end{array}$
penting dalam model perubahan perilakunya (Witte, K., 1997).

Tabel

Model Perubahan Perilaku

\begin{tabular}{|c|c|c|}
\hline Elemen Kunci & Definisi & Strategi Perubahan Perilaku \\
\hline Threat & $\begin{array}{lr}\text { Bahaya atau peristiwa } \\
\text { berbahaya yang orang mungkin } \\
\text { atau mungkin } r \text { tidak } \\
\text { menyadarinya. }\end{array}$ & $\begin{array}{lcr}\text { Meningkatkan } & \text { kesadaran } & \text { bahwa } \\
\text { ancaman } & \text { itu } & \text { ada, } \\
\text { fokus pada tingkat keparahan dan } \\
\text { kerentanan. }\end{array}$ \\
\hline Fear & $\begin{array}{l}\text { Rangsangan emosional yang } \\
\text { disebabkan dari pengamatan } \\
\text { yang signifikan dan ancaman } \\
\text { pribadi yang relevan. }\end{array}$ & $\begin{array}{l}\text { Takut dapat kuat mempengaruhi perilaku } \\
\text { dan jika disalurkan dalam cara yang } \\
\text { tepat dapat memotivasi orang untuk } \\
\text { mencari informasi, tetapi dapat juga } \\
\text { menyebabkan orang untuk menolak hal } \\
\text { yang beresiko. }\end{array}$ \\
\hline $\begin{array}{l}\text { Response } \\
\text { Efficacy }\end{array}$ & $\begin{array}{lcr}\text { Persepsi } & \text { bahwa } & \text { respon } \\
\text { dianjurkan akan mencegah } & \text { man } \\
\text { ancaman dari kejadian. }\end{array}$ & $\begin{array}{l}\text { Memberikan contoh bukti bahwa } \\
\text { tanggapan direkomendasikan } \\
\text { menghindari ancaman. }\end{array}$ \\
\hline Self-Efficacy & $\begin{array}{l}\text { Persepsi individu atau percaya } \\
\text { diri pada kemampuannya untuk } \\
\text { melakukan respon yang } \\
\text { direkomendasikan. }\end{array}$ & $\begin{array}{llr}\text { Meningkatkan } & \text { kepercayaan individu } \\
\text { bahwa dirinya dapat merespon dan } \\
\text { membantu memastikan untuk } \\
\text { menghindari ancaman. }\end{array}$ \\
\hline Barriers & $\begin{array}{l}\text { Sesuatu yang akan mencegah } \\
\text { individu dari respon yang } \\
\text { direkomendasikan. }\end{array}$ & $\begin{array}{l}\text { Menyadari hambatan fisik atau budaya } \\
\text { yang mungkin ada, upaya untuk } \\
\text { menghapus hambatan. }\end{array}$ \\
\hline Benefits & $\begin{array}{l}\text { Konsekuensi } \begin{array}{l}\text { positif dari } \\
\text { performing rekomendasi respon. }\end{array} \\
\end{array}$ & $\begin{array}{l}\text { Mengkomunikasikan manfaat dari } \\
\text { melakukan respon yang dianjurkan. }\end{array}$ \\
\hline $\begin{array}{l}\text { Subjective } \\
\text { Norms }\end{array}$ & $\begin{array}{l}\text { Apa seorang individu berpikir } \\
\text { bahwa orang lain berpikir } \\
\text { mereka harus melakukan. }\end{array}$ & $\begin{array}{l}\text { Memahami dengan siapa individu } \\
\text { cenderung akan mematuhi. }\end{array}$ \\
\hline Attitudes & $\begin{array}{l}\text { Evaluasi individu atau } \\
\text { keyakinan tentang respon yang } \\
\text { dianjurkan. }\end{array}$ & $\begin{array}{l}\text { Mengukur sikap yang ada sebelum } \\
\text { mencoba untuk mengubah orang. }\end{array}$ \\
\hline Intentions & $\begin{array}{lr}\text { Rencana individu untuk } \\
\text { melaksanakan respon yang } \\
\text { direkomendasikan. }\end{array}$ & $\begin{array}{l}\text { Menentukan apakah niat asli atau proxy } \\
\text { untuk perilaku yang sebenarnya. }\end{array}$ \\
\hline Cues to Action & $\begin{array}{lrr}\text { Faktor eksternal atau internal } \\
\text { yang membantu individu } \\
\text { membuat keputusan tentang } \\
\text { tanggapan. }\end{array}$ & $\begin{array}{l}\text { Menyediakan komunikasi yang mungkin } \\
\text { akan memicu individu untuk membuat } \\
\text { keputusan. }\end{array}$ \\
\hline Reactance & $\begin{array}{lrr}\text { Ketika } & \text { seorang } & \text { individu } \\
\text { bereaksi } & \text { terhadap } & \text { respon } \\
\text { dianjurkan. } & & \\
\end{array}$ & $\begin{array}{l}\text { Pastikan individu tidak merasa telah } \\
\text { dimanipulasi atau tidak dapat menangkal } \\
\text { ancaman tersebut. }\end{array}$ \\
\hline
\end{tabular}

Teori kognitif sosial Bandura A. (1986) mengusulkan tentang banyak orang didorong bukan oleh kekuatan batin, tetapi dengan faktor eksternal. Model ini menunjukkan bahwa fungsi manusia dapat dijelaskan adanya interaksi 
perilaku, pribadi dan faktor lingkungan. Hal ini dikenal sebagai reciprocal determinism. Faktor lingkungan merupakan pengaruh situasional dan lingkungan di mana perilaku ditunjukkan pada faktor personal yang meliputi naluri, pengendalian, sifat, dan kekuatan motivasi individu lainnya. Variabel-variabel dalam proses perubahan perilaku (Perry, C. L., Barnowski, T., \& Parcel, G. S. 1990), diantaranya self-efficacy, outcome expectations, self-control, reinforcements, emosional coping, observational learning.

\section{Gambar}

\section{Model Planned Behavior}

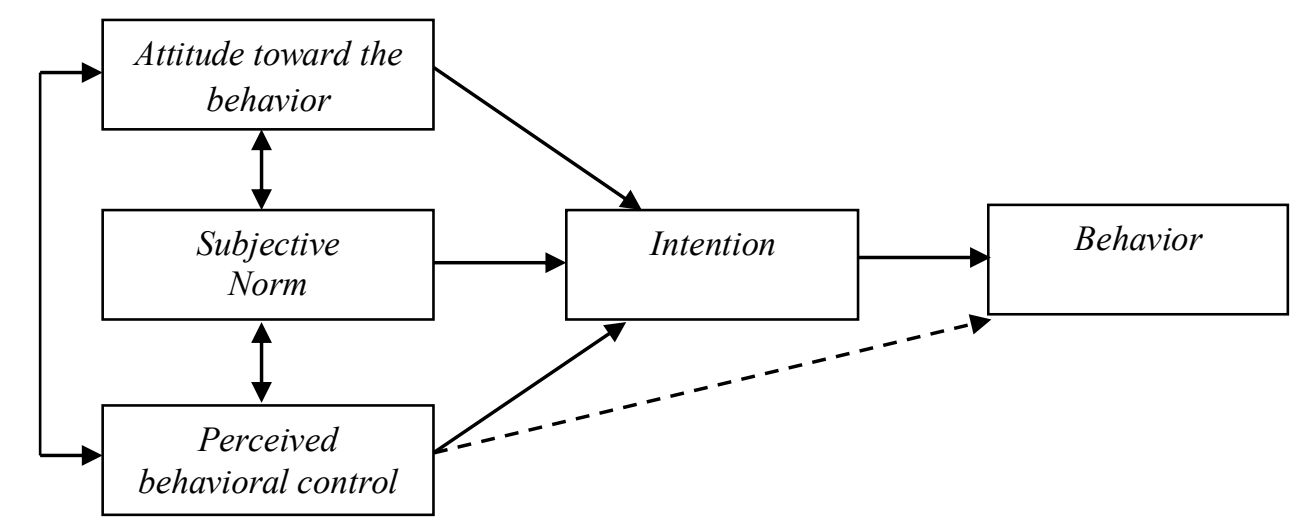

Sumber: Communication for Governance \& Accountability Program (CommGAP) The World Bank, www.worldbank.org/commgap, 2016

Model teori perilaku yang direncanakan (Ajzen, I. (1991), Armitage, C. and Conner, M. (2001), Grizzell, J. (2007)), menunjukkan perilaku yang tergantung pada niat seseorang untuk melakukan perilaku. Niat ditentukan sikap individu (keyakinan dan nilai-nilai tentang hasil dari perilaku) dan norma subjektif (keyakinan tentang apa yang orang lain pikirkan dan orang harus melakukan atau keyakinan terhadap tekanan sosial). Perilaku juga ditentukan perilaku yang dikontrol moral individu, didefinisikan sebagai persepsi individu untuk kemampuannya atau perasaan self-efficacy untuk melakukan tingkah laku, hubungan ini tergantung pada jenis hubungan dan sifat situasi.

Transtheoretical model (Prochaska, J., Johnson, S., and Lee, P. (1998)) mengusulkan perubahan tahap dalam enam proses. Precontemplation adalah tahap di mana orang tidak berniat untuk membuat perubahan dalam waktu dekat (6 bulan ke depan). Kontemplasi adalah tahap di mana orang berniat untuk mengubah (6 bulan berikutnya). Aksi adalah tahap di mana orang membuat perubahan perilaku dan memelihara pada tahap di mana orang mencegah untuk kembali. Terakhir, terminasi merupakan tahap di mana individu memiliki 100 persen dan akan menjaga perilakunya. Perubahan 
perilaku tidak selalu menjadi tujuan, mungkin menjadi prioritas untuk mengubah sikap atau opini publik tentang beberapa hal untuk mendefinisikan proses perubahan sikap. Zanna dan Rempel (1988), melihat sikap memiliki banyak penyebab. Sikap tidak stabil, tetapi sebagai sesuatu yang mungkin berubah berdasarkan pengaruh internal atau eksternal. Sikap dihasilkan dari kognisi (sumber informasi), afeksi (rasa, emosi yang terkait dengan obyek yang dapat mempengaruhi sikap), dan perilaku masa lalu. Hal ini merupakan sesuatu yang penting yang secara konsisten dan kongruen dapat membentuk sikap tunggal terhadap objek.

Menurut James F. Engel, Roger D. Blackwell, Paul W. Miniard dalam Saladin (2003: 19) terdapat tiga faktor yang mempengaruhi perilaku konsumen yaitu pengaruh lingkungan, terdiri dari budaya, kelas sosial, keluarga dan situasi. Perbedaan dan pengaruh individu, terdiri dari motivasi dan keterlibatan, pengetahuan, sikap, kepribadian, gaya hidup, dan demografi. Proses psikologis, terdiri dari pengolahan informasi, pembelajaran, perubahan sikap dan perilaku. Boyd, Jr. dan Walker Jr. (1995), proses pengambilan keputusan ketika akan melakukan pembelian bervariasi dari satu konsumen ke konsumen lainnya. Assael (1998) menyebutkan proses konsumen membuat keputusan pembelian harus dipahami dalam pengembangan aplikasi strategik. Pembelian dengan keterlibatan rendah tidak terlalu penting bagi konsumen dan resiko keuangan, sosial dan psikologi (Assael, 1998;
Boyd, Jr. dan Walker Jr., 1995). Perilaku pembelian tidak mempertimbangkan fungsi riil dan kualitas atas sebuah barang, dan dengan mudahnya mengadopsi nilai, sikap, perasaan, dan gaya hidup yang ditawarkan. Oleh karena itu, perilaku belanja termasuk perilaku shopping addiction, Edwards (1993) menyatakan bahwa perilaku ini merupakan suatu aktivitas berbelanja yang sifatnya abnormal. Konsumen akan memiliki kekuatan yang kuat, tidak terkontrol, kronis, dan memiliki keinginan yang berulang dalam berbelanja. Pelaku shopping addiction cenderung tidak mampu mengendalikan keinginannya atau mengontrol dirinya untuk berbelanja (shopping), dan akan melakukan upaya yang berulang dan terus menerus agar keinginannya dapat terpenuhi, dan tidak mampu untuk mengontrol diri (Moeljosoedjono, 2008). Shopping addiction dapat disebabkan oleh beberapa faktor. Siregar (2010) menyatakan bahwa shopping addiction disebabkan oleh faktor yang berasal dari diri sendiri, keluarga, dan lingkungan. Faktor yang dilihat diri sendiri, pelaku biasanya memiliki kebutuhan emosi yang tidak terpenuhi, kurang percaya diri, dan tidak berpikir secara positif tentang dirinya sendiri dan beranggapan bahwa belanja bisa membuat dirinya lebih baik. Senajutnya adalah faktor keluarga, kondisi keuangan keluarga yang berlebih, juga secara tidak langsung akan mempengaruhi perilaku konsumtif, serta dapat mempengaruhi anggota keluarga lain menjadi pelaku shopping addiction. Terakhir adalah faktor lingkungan juga dapat menjadi faktor perilaku 
ini muncul pada individu. Lingkungan pergaulan menjadi upaya pembenaran dalam perilaku ini, hal ini karena memiliki teman sama dalam hobi untuk berbelanja, dan dapat menimbulkan rasa ingin meniru dan memiliki juga apa yang dimiliki oleh temannya.

Selain itu juga, hal yang mendorong terjadinya perilaku shopping addiction adalah gaya hidup. Kotler (2001) telah menyatakan bahwa gaya hidup merupakan pola interaksi seseorang yang diungkapkan dalam kegiatan, minat, dan pendapat seseorang. Salah satu gaya hidup yang saat ini telah mengidap pada banyak masyarakat adalah gaya hidup hedonisme. Prinsip hedonisme ini menganggap bahwa hal yang baik merupakan sesuatu yang mendatangkan kesenangan, sedangkan sesuatu yang mendatangkan kesusahan, penderitaan, atau tidak menyenangkan merupakan hal yang tidak baik. Prinsip hedonisme menjadikan kesenangan sebagai tujuannya hidupnya. Gaya hidup hedonisme bisa muncul pada siapa saja, baik remaja maupun dewasa terutama untuk mengisi waktu luang, hiburan, maupun berbelanja di pasar modern, misalnya minimarket, toserba, swalayan, mall atau shopping centre jenis lainnya. Hal ini karena tempat tersebut, memiliki sejumlah barang dengan merekmerek tertentu dan prestisius serta cenderung mengikuti mode yang sedang tren. Kecenderungan gaya hidup hedonism akan menjadi pemicu bagi masyarakat yang mempersepsikan dirinya sebagai human having, yaitu seseorang yang mempersepsikan orang lain berdasarkan apa yang dimilikinya (Rema, 2012). Hal ini mengakibatkan seseorang akan merasa kekurangan secara terus menerus, dan dihinggapi perasaan cemas. Terlebih dorongan penawaran melalui iklan-iklan, promo, dan janjijani melalui media banyak yang mendorong gaya hidup hedonis dan konsumtif muncul, akibatnya individu akan berupaya untuk mendapatkannya dan dianggap mampu mengobati kegelisahannya.

\section{Gaya Hidup Hedonisme}

Sikap adalah perasaan seseorang tentang obyek, aktifitas, peristiwa dan orang lain. Sikap dapat mengalami perubahan sebagai akibat dari pengalaman. Tesser (1993) berargumen bahwa faktor bawaan dapat mempengaruhi sikap tapi secara tidak langsung. Carl Jung mendefinisikan tentang sikap sebagai kesiapan dari psike untuk bertindak atau bereaksi dengan cara tertentu. Sikap sering muncul dalam bentuk pasangan, satu disadari sedang yang lainnya tidak disadari. Melalui sikap, kita memahami proses kesadaran yang menentukan tindakan nyata dan yang tindakan yang mungkin dilakukan individu dalam kehidupan sosialnya. Thomas \& Znaniecki (1920) menegaskan bahwa sikap adalah predisposisi untuk melakukan atau tidak melakukan suatu perilaku tertentu, sehingga sikap bukan hanya kondisi internal psikologis yang murni dari individu (purely psychic inner state), tetapi sikap lebih merupakan proses kesadaran yang sifatnya individual. Artinya proses ini terjadi secara subjektif dan unik pada diri setiap individu. Keunikan ini dapat terjadi oleh adanya 
perbedaan individual yang berasal dari nilai-nilai dan norma yang ingin dipertahankan dan dikelola oleh Individu (Coser, dalam www.bolender.com). Thurstone \& Chave (dalam Mitchell, 1990) mengemukakan definisi sikap sebagai: "The sum total of a man's inclination and feelings, prejudice or bias, preconceived notions, ideas, fears, threats, and convictions about any specific topic" (hal. 532) Sikap adalah keseluruhan dari kecenderungan dan perasaan, curiga atau bias, asumsi-asumsi, ide-ide, ketakutan-ketakutan, tantangantantangan, dan keyakinan-keyakinan manusia mengenai topik tertentu.

Materialisme berasal dari kata materia (bahasa Latin) yang berarti bahan, benda, atau barang. Materialisme adalah pandangan yang menganggap bahwa segala sesuatu itu hanyalah benda atau barang; tidak lebih, tidak kurang. Penganut paham ini tidak mengakui adanya roh atau jiwa. Materialisme termasuk salah satu dalam tiga sikap mentalitas, selain konsumerisme dan hedonisme yang berjalan beriringan bagaikan tiga serangkai. Orang-orang yang menganggap bahwa hidup ini hanya untuk kenikmatan (hedonis) mencaricari barang-barang untuk memuaskan dirinya (materialis) dan mengakibatkan perilaku konsumeristis atau pemborosan. Gaya hidup modern dalam balutan wajah materialisme yang dijadikan panutan masyarakat adalah hasil copy paste dari berbagai tayangan televisi, tuntutan peradaban ilmu dan teknologi, serta kemudahan dalam mendapatkan pilihan dan pelayanan yang memanjakan. Modern, bergengsi, menyenangkan adalah keinginan masyarakat pedesaan dalam membangkitkan desakan emosi ataupun proses lain yang hampir tidak terkontrol oleh setiap individu. Sehingga sikap materialisme dapat dikatakan sebagai salah satu penyebab pergeseran sikap dan budaya individualistis masyarakat, yang mengharapkan suatu kekuasaan, keinginan dalam penyampaian hasrat dalam pencapaian tujuan, serta mengarah kepada kehidupan yang serba hedonism.

Hedonisme merupakan pandangan hidup yang menganggap bahwa orang akan menjadi bahagia dengan mencari kebahagiaan sebanyak mungkin dan sedapat mungkin menghindari perasaanperasaan yang menyakitkan. Hedonisme merupakan ajaran atau pandangan bahwa kesenangan atau kenikmatan merupakan tujuan hidup dan tindakan manusia. Terdapat tiga aliran pemikiran dalam hedonis yakni Cyrenaics, Epikureanisme, dan Utilitarianisme. Hedonisme diambil dari bahasa Yunani hedonismos dari akar kata hedone, artinya kesenangan. Paham ini berusaha menjelaskan adalah baik apa yang memuaskan keinginan manusia dan apa yang meningkatkan kuantitas kesenangan itu sendiri. Tokohnya diantaranya adalah Aristippus, Epikuros, dan Jeremy Bentham. Gaya hidup hedonis adalah suatu pola hidup yang mencari kesenangan seperti, banyak menghabiskan waktu diluar rumah, lebih banyak bermain, senang membeli barang-barang yang berharga mahal. Perilaku hedonisme saat ini sudah sangat melekat pada sebagian masyarakat Indonesia terutama masyarakat yang tinggal 
dikota-kota besar. Dimana perilaku hidup seperti ini bersifat negative karena hanya mementingkan kenikmatan, kesengan dan kepuasaan yang semuanya bersifat duniawi.

Menurut Mowen dan Minor (2002) gaya hidup ini memiliki beberapa aspek berupa pernyataan AIO yang digunakan untuk mengetahui gaya hidup, yaitu: pertanyaan aktivitas (activity questions), dimana meminta konsumen mengindikasi apa yang mereka lakukan, apa yang mereka beli, dan bagaimana mereka menghabiskan waktu mereka. Selanjutnya berkaitan dengan pertanyaan minat (interest question), yang memfokuskan pada preferensi dan prioritas konsumen. Akhirnya adalah berkaitan dengan pertanyaan opini (opinion question) yang menyelidiki pandangan dan perasaan konsumen mengenai topik-topik peristiwa dunia, lokal, moral, ekonomi dan sosial. Menurut Well dan Tigert (Engel, 1993), ada tiga aspek dalam gaya hidup hedonis yaitu pertama minat yang diartikan sebagai apa yang menarik dari suatu lingkungan individu tersebut dalam memperhatinkannya. Minat dapat muncul terhadap suatu objek, peristiwa, atau topik yang menekan pada unsur kesenangan hidup. Antara lain adalah fasion, makanan, bendabenda mewah, tempat berkumpul, dan selalu ingin menjadi pusat perhatian. Kedua yaitu aktivitas, yaitu cara individu menggunakan waktunya yang berwujud tindakan nyata yang dapat dilihat. Misalnya lebih banyak menghabiskan waktu diluar rumah, lebih banyak membeli barang-barang yang kurang diperlukan, pergi ke pusat pembelanjaan dan cafe. Terakhir, opini yaitu pendapat seseorang yang diberikan dalam merespon situasi ketika muncul pernyataanpernyataan atau tentang isu-isu sosial dan produk-produk yang berkaitan dengan hidup. Hedonisme yang ada di kalangan masyarakat Indonesia saat ini tidak dapat dihindari dalam berbagai aspek kehidupan. Pandangan yang terangkum dalam pandangan Epikuris menyatakan, bergembiralah engkau hari ini, puaskanlah nafsumu, karena besok engkau akan mati. Kemajuan zaman, gaya hidup hedonis menjadi semakin merajalela meracuni masyarakat, misalnya menyebarnya tempattempat hiburan untuk bersenangsenang, berfoya-foya, berjudi, minum-minuman keras, berzina dan sebagainya. Selain itu, menghamburkan uang utuk pergi ke pusat perbelanjaan untuk memuaskan segala keinginannya. Hedonisme juga merubah gaya berpakaian bagi para faham yang menganutnya. Kondisi ini akan menempatkan segala bentuk kemajuan zaman sebagai hal yang baik dan benar, padahal tidak semua bentuk kemajuan zaman sesuai dengan budaya masyarakat kita.

Penelitian yang berkaitan dengan masalah perilaku telah banyak dilakukan dan pada obyek yang berbeda-beda serta suasana yang mempengaruhinya. Penelitian Wendy L. Billings (1990) yang meneliti tentang efek dari suasana toko yang mempengaruhi perilaku berbelanja. Penelitiannya menemukan bahwa konsumen cenderung akan menunjukkan perilaku pendekatan yang lebih dalam dengan lingkungan 
menyenangkan. Hasil penelitian juga menunjukkan interaksi antara seks dan kesenangan, dan penelitian lebih lanjut diperlukan untuk mengembangkan taksonomi stimulus pada lingkungan ritel yang berhubungan dengan dimensi emosional. Penelitian Francis Piron (1991), menemukan prevalensi pembelian yang dilakukan sebagai pendorong, namun belum sepenuhnya menangkap fenomena tersebut, dan pada gilirannya tidak akurat untuk mencerminkan besarnya kegunaan pembelian impuls. George J. Szybillo and Arlene Sosanie (1977), menunjukkan penelitian di masa depan perlu mempertimbangkan potensi keterlibatan anak-anak dalam pengambilan keputusan keluarga. Dauzan dan Anita (2011) meneliti mengenai potret gaya hidup hedonisme di kalangan mahasiswa dan memberikan kesimpulan faktor penyebab gaya hidup hedonisme pada mahasiswa berasal dari pergaulan yang juga memiliki gaya hidup hura-hura dan terkesan bermewah-mewah, ada pula faktor lingkungan mengenai tindakan menyimpang dari lingkungan di tempat tinggal disekitarnya.

Melihat tinjauan teori dan penelitian yang dilakukan peneliti terdahulu, dapat dilihat perkembangan dan perubahan peradaban pada ilmu, teknologi dan informasi, dapat mendorong masyarakat merubah pola konsumsinya. Melihat kenyataan tersebut, maka kerangka maupun konsep berpikir peneliti adalah seberapa besar dampak dari perkembangan kemajuan peradaban terhadap gaya hidup hedonisme dan pola perilaku pembelian masyarakat pada saat ini. Penelitian ini ditinjau dari keberadaan pasar modern terhadap gaya hidup hedonisme yang memberikan kenyamanan dan memanjakan masyarakat saat ini. Sehingga peneliti membuat jawaban sementara atas pertanyaan penelitiannya yaitu terdapat adanya peran gaya hidup hedonisme yang dilihat dari aktivitas, minat, dan opini masyarakat dalam menjelaskan perilaku pembelian.

\section{METODE PENELITIAN}

Penelitian ini menggunakan variabel penelitian perilaku pembelian dalam pengambilan keputusan pembelian konsumen yang dipengaruhi perilaku hedonism masyarakat. Perilaku ini akan menggunakan skala shopping addiction yang dikembangkan Elizabeth E. Edwards (1993) yang disusun berdasarkan lima dimensi yaitu pertama adalah tendency to spend, drive to spend, feelings about shopping, , dysfunctional spending, post-purchase guilt. Sedangkan gaya hidup hedonism dimensi dalam pengukuran ini adalah pada skala gaya hidup hedonisme yang peneliti susun berdasarkan tiga dimensi konsep teori gaya hidup yang dikemukakan oleh Well dan Tigert (Engel, 1993), Kotler dan Amstrong (2008), Mowen dan Minor (2002), dengan karakteristik-karakteristik hedonism yaitu aktivitas, interest, dan opini. Penelitian ini dirancang untuk mengetahui dampak gaya hidup hedonisme terhadap perilaku pembelian masyarakat kabupaten Kebumen saat ini. Penelitian ini diawali dengan melihat faktor-faktor yang mempengaruhi gaya hidup 
hedonisme, selanjutnya dampak munculnya sikap- perilaku pembelian yang abnormal, terutama yang ada di pasar modern.

Metoda yang digunakan dalam penelitian ini adalah metoda survei, yaitu metoda pengumpulan data primer melalui kuesioner yang representatif. Subjek penelitian ini adalah masyarakat kabupaten Kebumen yang berbelanja di pasar modern. Objek penelitian ini adalah perilaku/ aktivitas pembelian masyarakat Kebumen yang melakukan pembelian di pasar modern yang abnormal. Perubahan ini dikaji pada perubahan gaya hidup masyarakat yang menuju hedonis dengan mengesampingkan aspekaspek lain seperti masalah kebersihan dan kenyamanan, lebih kepada masalah gaya hidup. Pertimbangan tersebut didasari dengan semakin tumbuh dan berkembangnya pasar modern di kabupaten Kebumen terutama untuk industri ritel lokal dan regional yang sedang berkembang. Metoda sampling yang digunakan dalam penelitian ini adalah nonprobabilistic sampling, yaitu setiap elemen dalam populasi tidak memiliki probabilitas yang sama untuk menjadi sampel (Sekaran, 1992; Cooper \& Emory, 1995; Cooper \& Schindler, 2001). Jenis teknik penentuan sampel secara non probabilitas yang digunakan dalam penelitian ini adalah sampling insidental, yaitu teknik penentuan sampel berdasarkan kebetulan, yaitu siapa saja yang secara kebetulan atau insidental bertemu dengan peneliti dapat digunakan sebagai sampel, bila dipandang orang yang kebetulan ditemui itu cocok sebagai sumber data (Sugiyono, 2007). Alasan terhadap pemilihan teknik ini adalah untuk membedakan dengan tidak memberikan peluang yang sama bagi pengunjung di pasar modern yang ada di Kebumen, dan yang hanya memenuhi kriteria penelitian saat ini. Penelitian ini akan membagikan pertanyaan melalui kuesioner sebanyak 100 eksemplar kepada responden. Sebelum dilakukan analisis terhadap data yang terkumpul, peneliti akan melakukan uji validitas dan reliabilitas terhadap instrumen penelitian. Setelah instrumen memenuhi tingkat validitas dan reliabilitas, maka selanjutnya dilakukan analisis setelah proses pengumpulan data selesai dilakukan, melalui analisis kualitatif dan kuantitatif. Analisis kualitatif dilakukan dengan menggunakan hasil dari pengumpulan data yang digambarkan dengan kata-kata atau kalimat dipisah-pisahkan, ataupun menggunakan tabel-tabel berdasarkan hasil dari responden. Data-data tersebut adalah jenis kelamin, tingkat pendidikan, alasan pembelian dan motivasi datang ke pasar modern, dan akses untuk mendapatkan informasi pasar modern itu sendiri. Sedangkan analisis kuantitatif dilakukan untuk mencapai tujuan penelitian dan menguji hipotesis. Analisis tersebut diawali dengan memasukkan datadata yang ada ke dalam model analisis regresi linear berganda, dan selanjutnya dioperasionalisasikan pengolahan datanya dengan menggunakan alat bantu analisis SPSS versi 23.0.

\section{HASIL DAN ANALISIS}

Penelitian ini bertujuan untuk mengetahui gaya hidup 
hedonisme terhadap perilaku pembelian konsumen masyarakat kabupaten Kebumen dengan tumbuh dan berkembangnya pasar modern saat ini. Setelah dilakukan uji instrumen dilakukan dan memenuhi kriteria sebagai kuesioner, maka dilakukan penyebaran kuesioner kepada responden, dan hasilnya menunjukkan kuesioner layak dan absah dipakai untuk penelitian ini. Setelah dilakukan penelitian mengenai profil responden, dapat ditemukan bahwa responden yang terbanyak adalah perempuan dengan $81 \%$ dan sisanya adalah laki-laki. Pendidikan responden didominasi oleh pendidikan SMA/ Sederajat sebanyak $83 \%$ dan sisanya terdistribusi pilihan lainnya. Sedangkan frekuensi pembelian ratarata belanja di pasar modern masih cukup normal disekitar 2-3 kali per bulan dengan jumlah $71 \%$ dari total responden. Alasan pembelian berdasarkan keluarga pada aspek yang mempengaruhi keputusan berbelanja menjadi mendominasi yaitu $18 \%$, sisanya terdistribusi karena adanya pengakuan, kenyamanan, kebutuhan dasar, hasrat untuk berbeda, memilih produk yang baik, hasrat untuk berhubungan, emosional dan pengembangan diri. Responden mendapatkan akses berbelanja pada pasar modern berasal dari keluarga yang paling dominan, yaitu $33 \%$ dan sisanya terdistribusi karena pengalaman, teman, tetangga, sumber komersial, sumber publik. Sebelum dilakukan pengujian terhadap regresi berganda, sebelumnya perlu dilakukan pengujian terhadap instrumen penelitian kepada responden yang telah dilakukan sebelumnya, yakni uji asumsi klasik yang harus dipenuhi agar kesimpulan tidak bias, yaitu uji normalitas, uji multikolinieritas, uji autokorelasi, uji heteroskedastisitas dan uji linieritas dan semua kriteria telah terpenuhi. Pengaruh aktivitas $\left(\mathrm{X}_{1}\right)$, minat $\left(\mathrm{X}_{2}\right)$ dan opini $\left(\mathrm{X}_{3}\right)$ terhadap shopping addiction $(\mathrm{Y})$ dapat dilihat dengan menggunakan analisis regresi linier berganda dengan hasil $\mathrm{F}$ hitung adalah 13,393 dengan tingkat signifikansi 0,000 , sehingga variabel aktivitas, minat, dan opini berpengaruh bersama-sama terhadap shopping addiction. Pengujian secara parsial dilakukan pengujian koefisien regresi dengan menggunakan statistik uji t. Penentuan hasil pengujian ditentukan dengan perbandingan nilai t hitung dan t tabel. Pada aspek aktivitas masyarakat sebesar 2,442 dengan tingkat signifikansi 0,016 < 0,05 , ini berarti variabel aktivitas berpengaruh signifikan terhadap shopping addiction. Hedonisme merupakan pandangan hidup yang menganggap bahwa orang akan menjadi bahagia dengan mencari kebahagiaan sebanyak mungkin dan sedapat mungkin menghindari perasaan-perasaan yang menyakitkan. Aktivitas dari gaya hidup ini dilakukan untuk mencari kesenangan seperti, banyak menghabiskan waktu diluar rumah, lebih banyak bermain, senang membeli barang-barang yang berharga mahal. Pertanyaan mengenai aktivitas (activity questions), dilakukan dengan meminta konsumen menjawab alasan yang mengindikasikan apa saja yang mereka lakukan, apa yang mereka beli, dan bagaimana mereka 
menghabiskan waktu mereka terutama dalam pasar modern yang menjadi obyek dalam penelitian ini. Berdasarkan analisis yang dilakukan mengenai aktivitas masyarakat menjadi salah satu faktor yang dapat mempengaruhi shopping addiction (perilaku pembelian yang abnormal). Peningkatan aktivitas masyarakat dalam melakukan perilaku berbelanja akan meningkatkan perilaku belanja yang abnormal. Hal ini memperkuat teori Mowen dan Minor (2002) yang menyimpulkan bahwa aktivitas masyarakat dalam berbelanja menjadi bagian dari gaya hidup hedonisme dan menjadi alasan/ penyebab perilaku pembelian yang abnormal. Disamping itu, hasil ini bisa membuktikan bahwa gaya hidup hedonis telah menyebar pada setiap elemen masyarakat di Kebumen, dimana rata-rata lebih menyukai pada suasana toko dalam pembelian (Wendy L. Billings, 1990), yang menyebabkan adanya perilaku pembelian impulse (Francis Piron, 1991). Potensi keterlibatan anakanak dalam pengambilan keputusan pembelian abnormal saat ini telah begitu kuat karena pendidikan dan akses teknologi informasi yang lebih cepat dibandingkan orang tuanya (George J. Szybillo and Arlene Sosanie, 1977; D.,P., Dauzan dan D., Anita, 2011).

Minat terhadap shopping addiction diketahui nilai t-hitung sebesar 2,739 dengan tingkat signifikansi $0,007<0,05$, ini berarti variabel minat berpengaruh signifikan terhadap shopping addiction. Pada saat ini kemajuan teknologi informasi telah menawarkan berbagai macam gaya hidup kepada masyarakat. Banyak diantaranya berlomba-lomba untuk mengikuti tren gaya hidup untuk mencapai kepuasaan pribadi yang kadang-kadang menjerumus kepada hal-hal yang bersifat negatif. Minat (interest), memfokuskan pada preferensi dan prioritas konsumen. Peningkatan minat masyarakat dalam melakukan perilaku berbelanja akan meningkatkan perilaku belanja yang abnormal, termasuk mendukung apa yang disampaikan teori Mowen dan Minor (2002). Minat dapat muncul terhadap suatu objek, peristiwa, atau topik yang menekan pada unsur kesenangan hidup. Antara lain adalah fasion, makanan, benda-benda mewah, tempat berkumpul, dan selalu ingin menjadi pusat perhatian. Hasil ini bisa membuktikan bahwa gaya hidup hedonis yang berkaitan dengan minat berbelanja telah menyebar pada setiap elemen masyarakat di Kebumen, dengan melihat suasana toko dalam pembelian (Wendy L. Billings, 1990), perilaku pembelian impulse (Francis Piron, 1991) serta adanya keterlibatan anak-anak dalam pengambilan keputusan pembelian abnormal (George J. Szybillo and Arlene Sosanie, 1977; D., P., Dauzan dan D., Anita, 2011).

Pengaruh opini terhadap shopping addiction berdasarkan output diketahui nilai t-hitung sebesar 3,439 dengan tingkat signifikansi $0,001<0,05$, ini berarti variabel opini berpengaruh signifikan terhadap shopping addiction. Opini (opinion) merupakan pandangan dan perasaan konsumen mengenai topiktopik peristiwa dunia, lokal, moral, ekonomi dan sosial. Menurut Well dan Tigert (Engel, 1993), ada tiga aspek dalam gaya hidup hedonis 
yaitu pertama merupakan pendapat yang diberikan dalam merespon situasi ketika muncul pernyataanpernyataan atau tentang isu-isu sosial dan produk-produk yang berkaitan dengan hidup. Hasil penelitian ini membuktikan bahwa ukuran gaya hidup hedonis masyarakat Kebumen, adakalanya masyarakat menganggap dunia sangat membencinya karena adanya sesuatu masalah berat yang muncul, serta memiliki relativitas kenikmatan diatas rata-rata yang tinggi. Sehingga masyarakat berupaya mencoba untuk mengalihkan perhatiannya agar merasa dirinya nyaman dan dapat menikmati kehidupan. Hal ini bisa dibuktikan dengan gaya hidup hedonis terutama berbelanja untuk menghilangkan perasaan-perasaan negatif, dan hal ini juga telah ada pada masyarakat di Kebumen untuk mencari kenyamanan, dengan cara berbelanja ke pasar modern denga menikmati suasana toko (Wendy L. Billings, 1990), dan melakukan pembelian impulse yang bisa memberikan kenyamanan pada saat datang tiba-tiba (Francis Piron, 1991) serta adanya keterlibatan keluarga lain yang memberikan suasana berbeda saat mengambil keputusan untuk berbelanja (George J. Szybillo and Arlene Sosanie, 1977; D., P., Dauzan dan D., Anita, 2011).

Koefisien determinasi pada intinya mengukur seberapa jauh kemampuan model dalam menerangkan variasi variabel. Determinasi ini digunakan untuk menjelaskan kebaikan dari model regresi dalam variabel dependen. Dari hasil output SPSS tersebut dapat dilihat bahwa nilai koefisien determinasi atau Adjusted R Square sebesar 0,273 atau 27,3\%. Hal ini menunjukan bahwa variabel yang diteliti (aktivitas, minat dan opini) memberikan pengaruh terhadap sebesar $27,3 \%$ sedangkan selebihnya $72,7 \%$ dipengaruhi oleh variabel lain yang tidak diteliti (variabel pengganggu) dalam penelitian ini.

\section{PENUTUP}

Berdasarkan hasil analisis data yang telah diperoleh, maka dapat diambil kesimpulan sebagai berikut: Gaya hidup hedonism yang terdiri dari aktivitas, minat, dan opini masyarakat memiliki peran secara bersama-sama (simultan) dalam menjelaskan kecenderungan shopping addiction. Artinya bahwa unsur-unsur yang ada yang diakibatkan aktivitas, minat, dan opini masyarakat dalam berbelanja akan mendapatkan suatu perilaku pembelian yang abnormal. Akibatnya perilaku pembelian abnormal membuat masyarakat mengeluarkan biaya untuk mendapatkan produk yang belum tentu sesuai kebutuhan, melainkan keinginan dan emosional dalam pengambilan keputusan pembeliannya.

Berdasarkan hasil penelitian dan kesimpulan yang telah diperoleh, maka peneliti memberikan beberapa saran pada aspek metodologis agar penelitian selanjutnya, dapat menggunakan karakteristik aspek sosiologis, psikologis, antropologis, budaya, maupun faktor-faktor demografis lainnya sebagai variabel yang menjelakan kecenderungan shopping addiction. Konsumen dengan kategori shopping addiction tinggi, disarankan dapat melakukan perencanaan sebelum melakukan 
proses pengambilan keputusan pembelian, dan tidak mengalihkan segala bentuk ketidaknyaman pada masalah pribadi kepada aktivitas berbelanja. Keluarga memiliki peran yang penting bagi perkembangan peradaban yang perlu diikuti pada manusia saat ini. Keluarga juga dapat mengajarkan gaya hidup hedonisme sejak dini, baik dari orang tua ke anak ataupun sebaliknya. Oleh karena itu orang tua dan anak perlu saling menjaga untuk mengendalikan pola berbelanja yang didasarkan karena aspek kebutuhan.

\section{Daftar Pustaka}

agung.st-albertus.sch.id/ wp content/uploads/2008/11/me lawan konsumerisme.doc

Ajzen, I. 1991. The Theory of Planned Behavior. Organizational Behavior and Human Decision Processes, 50, 179-211.

Armitage, C., \& Conner, M. (2001). Efficacy of the theory of planned behaviour: A metaanalytic review. British Journal of Social Psychology, 40, 471-499.

Assael, Henry, 1998, Consumer Behavior and Marketing Action. $6^{\text {th }}$ edition. Cengage Learning.

Bandura, A. 1986. Social Foundations of Thought and Action. Englewood Cliffs, New Jersey: Prentice-Hall.
Billings, Wendy L., 1990, "Effects of Store Atmosphere on Shopping Behavior". Honors Projects. Paper 16. http://digitalcommons.iwu. edu/busadmin honproj/16.

Duncan, Tom. 2005. Principles of Advertising \& IMC, Second Edition. McGraw-Hill, Inc. Bab 5

D.,P., Dauzan, dan D. Anita., 2011, Potret Gaya Hidup Hedonisme Di Kalangan Mahasiswa (Studi pada Mahasiswa Sosiologi FISIP Universitas Lampung), Jurnal Sociologie, Vol. 1, No. 3: 184-193.

Francis Piron (1991), "Defining Impulse Purchasing", in NA

- Advances in Consumer Consumer Research Volume 18, eds. Rebecca H. Holman and Michael R. Solomon, Provo, UT: Asosiasi Consumer Research, Page: 509-514.

George J. Szybillo and Arlene Sosanie, 1977, "Family Decision Making: Husband, Wife and Children", in NA Advances in Consumer Research Volume 04, eds. William D. Perreault, Jr., Atlanta, GA: Association for Consumer Research, Pages: 46-49.

Glanz, K., Lewis, F. M., \& Rimers, B. K. (Eds.), 1990, Health Behavior and Health 
Education: $\quad$ Theory, Research, and Practice. San Francisco, CA: Jossey-Bass.

Godin, G., \& Kok, G. 1995. The theory of planned behavior: A review of its applications to health-related behaviors. American Journal of Health Promotion, 11, 87-98.

Grizzell, J. (2007, 1/27/2007). Behavior Change Theories and Models. Retrieved January 28, 2007, from http://www.csupomona.ed u/ jvgrizzell/best practice/ bctheory.html.

Hasil penelitian kerjasama antara Deputi Bidang Pengkajian Sumberdaya UKMK, Kementerian Koperasi dan UKM dengan PT Solusi Dinamika Manajemen, tahun 2005, Penelitian Dampak Keberadaan Pasar Modern (Supermarket dan Hypermarket) Terhadap Usaha Ritel Koperasi/Waserda dan Pasar Tradisional, Jurnal Pengkajian Koperasi dan UKM Nomor 1 Tahun I2006.

Herek, G. (1986). The instrumentality of attitudes: Toward a neofunctional theory. Journal of Social Issues, 42:2, 99-114.

Hotniar Siringoringo, Peran Bauran Pemasaran Terhadap Perilaku Pembelian Konsumen, Jurnal Ekonomi
\& Bisnis No. 3, Jilid 9, Tahun 2004.

John W. Lounsbury, Lucy W.Gibson, Richard A. Saudargas, "Scale Development" dalam Frederick T.L. Leong and James T. Austin, 2006, The Psychology Research Handbook: A Guide for Graduate Students and Research Assistants (Thousand Oaks: Sage Publications, Inc) p.144.

Jung, C.G. (1966). Two Essays on Analytical Psychology, Collected Works, Volume 7, Princeton, NJ: Princeton University Press. ISBN 0691-01782-4

(http://id.wikipedia.org/wik i/Sikap)

Kim, M. S., \& Hunter, J. E. (1993). Relationships among attitudes, behavioral intentions, and behavior: A meta-analysis of past research, part 2. Communication Research, 20:3, 331-364.

M.F. Shellyana Junaedi, 2008, Dimensi Kolektivisme Dan Individualisme Dari Perubahan Sosial: NilaiNilai Orientasi Sebagai Konstruksi Identitas Dan Persepsi Kawula Muda, The 2nd National Conference UKWMS, Surabaya, 6 September 2008. 
Moeljosoedjono, H. K. (2008). Attachment Style Pada Wanita yang Mengalami Shopping Addiction. Skripsi. Universitas Indonesia. Diakses melalui http://digilib.ui.ac.id tanggal 17 Januari 2016.

Neila Ramdhani, 2008, Sikap dan Perilaku: Dinamika Psikologi Mengenai Perubahan Sikap dan Perilaku, tugas kuliah Independent Study.

Olson, Jerry and Paul Peter. 2008. Consumer Behavior \& Marketing Strategy, 7th edition. New York: McGraw Hill.

Perry, C. L., Barnowski, T., \& Parcel, G. S. 1990. How individuals, environments, and health behavior interact: Social learning theory. In K. Glanz, F. M. Lewis \& B. K. Rimer (Eds.), Health Behavior and Health Educaiton: Theory Research and Practice. San Francisco, CA: Jossey-Bass.

Perry Roy Hilton and Charlotte Brownlow, 2004, SPSS Explained, (East Sussex: Routledge p.364.

Rorlen, 2007, Peran Kelompok Acuan dan KeluargaTerhadap Proses Keputusan Untuk Membeli, Business and Management
Journal Bunda Mulia, Vol:3, No 2, September 2007.

Sinaga, Pariaman. 2004. Makalah Pasar Modern VS Pasar Tradisional. Kementerian Koperasi dan UKM. Jakarta: Tidak Diterbitkan.www.bolender.c om

Soeparto Tjitrodihardjo, 2004, Materialisme Sebagai Akar Masalah, Suara Merdeka: 01 Juni 2004, Suara Merdeka.

Witte, K. 1997. Research review theory-based interventions and evaluations of outreach efforts [electronic version]. Planning and Evaluating Information Outreach among Minority Communities: $\quad$ Model Development Based on Native Americans in the Pacific Northwest. Retrieved Juny 20, 2016 from

http://nnlm.gov/archive/pn r/eval/witte.html.

Zanna, M. P., \& Rempel, J. K. 1988. Attitudes: A new look at an old concept. In D. Bartal \& A. W. Kruglanski (Eds.), The social psychology of knowledge, 315-334. Cambridge, UK: Cambridge University Press. 